\title{
THE STORY OF THE 1833 FERCHER SURVEY, POSTOJNSKA JAMA, CONTINUES: AN ADDITIONAL DOCUMENT AND NEWLY DISCOVERED INSCRIPTIONS
}

\author{
ZGODBA FERCHERJEVE IZMERE POSTOJNSKE JAME (1833) SE \\ NADALJUJE: DODATNI DOKUMENTI IN NOVO ODKRITI NAPISI
}

by

Stephan KEMPE ${ }^{1}$, Hans-Peter HUBRICH ${ }^{2}$ \& Klaus SUCKSTORFF ${ }^{3}$

\begin{abstract}
:
UDC 551.442(497.4 Postojna)(091)

Stephan Kempe \& Hans-Peter Hubrich \& Klaus Suckstorff: The story of the 1833 Fercher survey, Postojnska jama, continues: An additional document and newly discovered inscriptions

Publications, archived documents and inscriptions help with the reconstruction of the history of Postojnska jama. Until recently, the circumstances of the first mayor cave survey ever undertaken were not well known. It is the so called Fercher Survey conducted in winter 1833; a cooperation between the Mine Office in Idrija and the Cave Administration that surveyed the entire cave known at the time. Documents from the Archive of the Karst Research Institute and an inscription in the Tartarus of Postojnska jama gave a first insight into this story (Kempe, 2005). The survey suggested that (in what is now Male jama) a connection could be blasted to shorten the visitor route. Now a further letter dated 5 th September, was found shedding light on this mining attempt begun in summer 1833. In the letter the Cave Administration massively attacks the Mine Office. They claim that either the survey was not accurate or that the breakthrough was attempted at a wrong site. In consequence they demanded their expenses back, threatening with an investigation by the precinct administration. We also found three more inscriptions of the Fercher Party, in Pisani rov and in the Old Cave, one by Fercher and two by the miner Tracha.
\end{abstract}

Key words: history of cave survey, Fercher, Postojnska jama, Slovenia.
Izvleček: $\quad$ UDK 551.442(497.4 Postojna)(091)

Stephan Kempe \& Hans-Peter Hubrich \& Klaus Suckstorff: Zgodba Fercherjeve izmere Postojnske jame (1833) se nadaljuje: dodatni dokumenti in novo odkriti napisi

Objavljena dela, arhivirani dokumenti in napisi pomagajo rekonstruirati zgodovino Postojnske jame. Do nedavna so bile okoliščine prve velike jamske izmere še ne dovolj poznane. Gre za t.im. Fercherjevo izmero v zimi 1833: v sodelovanju med Rudniškim uradom v Idriji in Jamsko upravo je bila izmerjena celotna do tedaj znana jama. Na podlagi dokumentov iz arhiva Inštituta za raziskovanje krasa in napisa v Tartarju (Postojnska jama) je bil mogoč prvi vpogled v to zgodbo. Na podlagi izmere je bil svetovan (v današnjih Malih jamah) preboj s pomočjo miniranja, ki bi obiskovalcem skrajšal pot. Najdeno je bilo pismo datirano s 5. septembrom, ki meče novo luč na ta rudarski podvig v začetku poletja 1833 . V tem pismu Jamska uprava hudo napada Rudarski urad. Zatrjujejo, da bodisi izmera ni bila pravilna ali pa je bil preboj napravljen na napačnem mestu. Zato zahtevajo nazaj plačilo stroškov ter grozijo s preiskavo preko ustrezne instance. Odkriti so bili še trije novi napisi Fercherjeve skupine, v Pisanem rovu in v Starih jamah, eden od samega Fercherja in dva od rudarja Trahe.

Ključne besede: zgodovina merjenja jam, Fercher, Postojnska jama, Slovenija.

\section{INTRODUCTION}

The reconstruction of the history of the discovery of Postojnska jama rests on the study of publications, ar- chived documents and inscriptions in the cave (among others: Shaw, 1992; Shaw \& Čuk, 2002; Kempe, 2003,

\footnotetext{
${ }^{1}$ Institute for Applied Geosciences, University of Technology Darmstadt, Schnittspahnstr. 9, D-64287 Darmstadt, Germany, email: kempe@geo.tu-darmstadt.de;

2 Am Langenmarkstein 31, D-64686 Lautertal;

${ }^{3}$ Rosenweg 42, D-21502 Geesthacht.
}

Received / Prejeto: 08.03.2006 

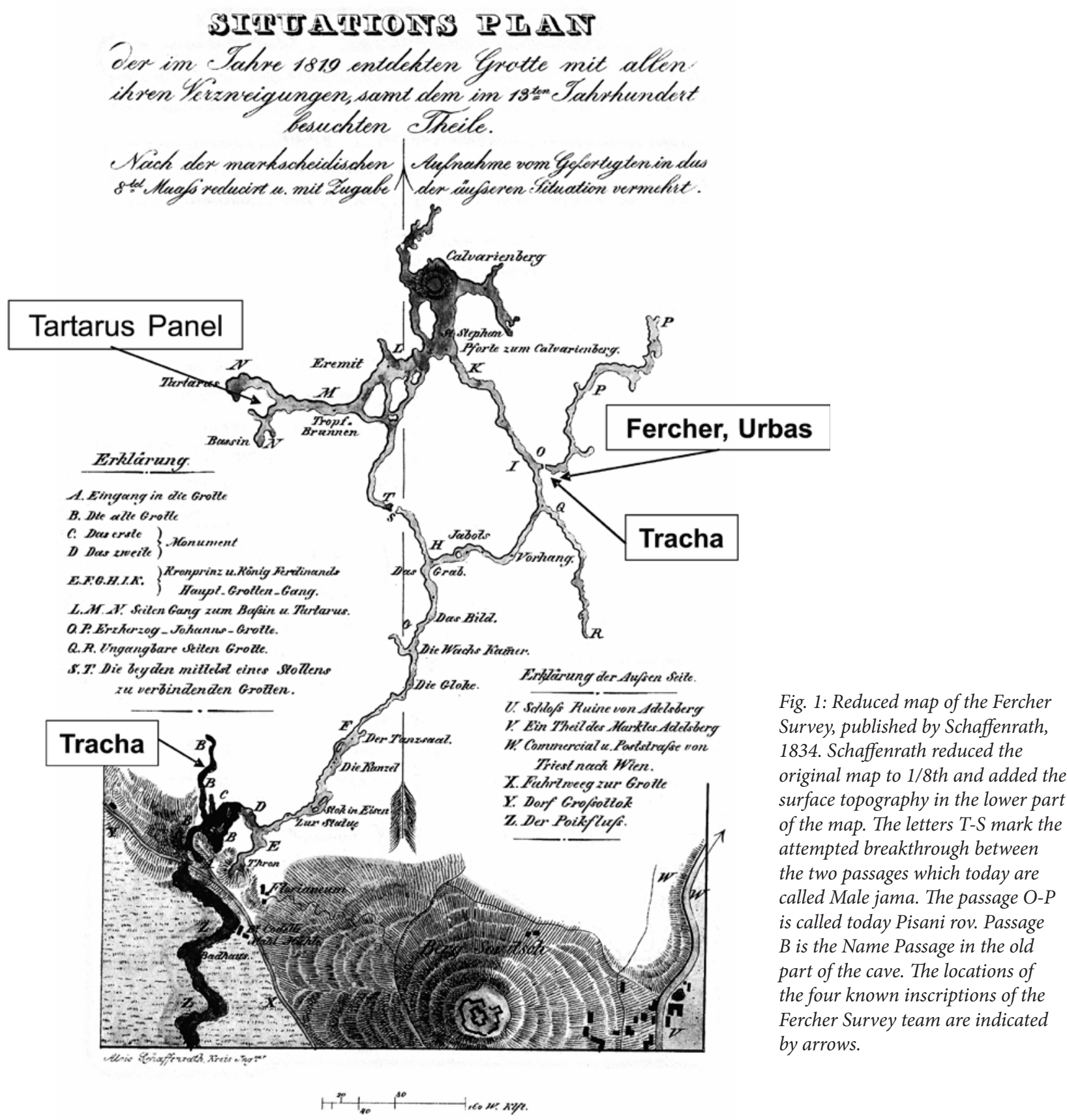

2005; Kempe et al., 2004; Kempe \& Henschel, 2004). Specifically the years immediately after the discovery of the main passage are not documented clearly in spite of the publications of Volpi (1821), Bronn (1826), Hohenwart (1830, 1832a,b), Schaffenrath (1834), and Schmidl (1854, 1858). Particularly the circumstances of the survey of the cave in 1833, the so-called Fercher Survey, remained unknown (Fig. 1). It was the largest highly professional survey conducted up to that point, with the Lee Survey of Mammoth Cave following a year later (Shaw, 1972). The publication of the Tartarus Panel, on which the members of the survey team left their names, gave opportunity to search for associated documents in the archive of the Karst Institute and of the Mines at Idrija. Four letters and notes have been found by the librarian of the Karst Institute, Maja Kranjc. These German language letters were written in Current handwriting, in use at the time for official documents. These letters have been transcribed and analyzed (Kempe, 2005). They show that the Grottenverwaltung (Grotto Commission) had asked the Bergamt (Mining Office) at Idrija for help with the survey. Accordingly the Bergamt had sent "Marktscheider" 
(surveyor) Michael Glantschnigg, "Huttmann" (mine supervisor) Johann Fercher, "Gehülfe" (helper) Aloys Urbas, "Fuhrmann" (coach man) Johann Leskovitz, "Bergmann" (miner) Johann Wruss and "Bergmann" Valentin Tracha to conduct the survey. Fercher, Urbas, Wruss and Tracha inscribed their names during the survey at the south-hand branch of the Tartarus on February $7^{\text {th }}, 1833$. Glanschigg and Leskovitz seem not to have been active in the cave. One of the results of the survey was that the two passages, today forming the Male jama, ended very closely to each other. The Grottenverwaltung therefore asked for help once more and the Bergamt sent Tracha on July $11^{\text {th }}$ with a supply of 50 pounds of black powder in order to open up this blockage between the passages. This attempt, however, failed and the Grottenverwaltung apparently complained about the inaccuracy of the survey with the Bergamt. This upset Fercher and he immediately wrote a rather angry letter on September $8^{\text {th }}$ to the Bergamt that transmitted it immediately to the Grottenverwaltung (document 986). Now the letter of the Grottenverwaltung, dated September $5^{\text {th }}$ was relocated in the Archive of the Karst Institute (Appendix 1) by Trevor Shaw and is transcribed here for the first time. In addition we found three further inscriptions of members of the Fercher party in different parts of the cave.

\section{THE LETTER OF THE GROTTENVERWALTUNG}

The letter is labeled "GV 52", "GV" standing for "Grottenverwaltung", dated September $5^{\text {th }}, 1833$, and is addressed to the "löbliche k.k. Bergamt" at Idrija, i.e. to the "honorable Imperial-Royal Mining Office" at the mercury mine at Idrija. Throughout the letter, this address is repeated several times shortened to "löbl.". Never a specific person, such as Fercher or Bergrat Prettmann (who signed two of the previous letters from Idrija; Kempe, 2005), is addressed directly. This is a specific characteristic of what is called (derogatorily) "Amtsdeutsch", the impersonal style of German-speaking administrations. It signals the power of the speaker as an official of state towards a "subject". Similarly, the signature of the letter is abstracted; here we think it should be read as "Letz" or "Betz", but it may also be abbreviated and stand for "Lenertz", (compare signature below No 57 GV, Oct. $8^{\text {th }}, 1833$, in Kempe, 2005), reminding of signatures of medical doctors in today's society. There are other illegible words in the letter, some of which we were able to deduce from the context, others remain illegible; luckily these are not essential for understanding the content. The entire note consists of ca. 2900 letters (without blanks) but has only eight sentences! Long and complicated sentences are another feature of "Amtsdeutsch" and even more so of the written German at the beginning of the $19^{\text {th }}$ century. Another peculiarity of the letter is the largely missing commas that make reading difficult. In order to make discussion of the text easier, we have inserted numbers in parentheses at the beginning of each of the eight sentences.

The entire letter is carefully crafted, starting with some compliments but ending with the demand to reimburse the Grottenverwaltung for the funds spent on the failed Male jama connection. One cannot avoid the impression that the Grottenverwaltung actually tries to blackmail the Mine Office!
Sentence (1) is the opening of the game: It states the fact that the Grottenverwaltung, trusting the Fercher survey, has "allowed" continued work at the potential connection. We learn that actually three persons are involved in this work, one mining official ("Bergbeamter") and two miners ("Bergarbeiter"). From Idrija office Note 747 we originally thought only one miner (Valentin Tracha) was commissioned to do this work (Kempe, 2005). We also learn that this work seems to have been going on continuously since early July. Twice the Idrija office is pacified by expressions like "gefällige Mitwirkung" and "Gefälligkeit" implying that the Grottenverwaltung is grateful for the help obtained in the matter.

Sentence (2) prepares for the attack: It states that the "Herr Kreishauptmann" (abbreviated) (Graf zu Brandis ${ }^{4}$ ) became suspicious ("Mißtrauen... eingeflößt”) because the breakthrough hasn't yet been made even though the survey ("nach dem Plan") showed only a thin layer ("dünne Schicht") which needed removal. This mistrust was further nourished by remarks of Fercher that he made during his last visit when he commented on the state of progress ("Mittheilungen .... über den Stand der dießfälligen Arbeiten"). It is interesting to note that Fercher here carries the title of a "prov. Oberhutmann" in contrast to document Idrija 429 in which he is listed simply as "Hutmann" (Kempe, 2005; Appendix). Possibly Fercher had received a pay

\footnotetext{
${ }^{4}$ Alois Schaffenrath dedicated his guide to the cave in which he reproduced the Fercher Survey in 1834 to "Seiner Hochund Wohlgeboren Herrn Clemens Grafen zu Brandis, Freiherrn zu Leonburg, Forst und Fahlburg, k.k. wirklichem Kämmerer Seiner Majestät, Gubernialrath und Kreishauptmann zu Adelsberg"; accordingly Brandis was Kreishauptmann and Kommissionspräses in 1834 and most probably also in 1833."
} 
raise and had advanced from mine supervisor to mine superintendent in the summer of 1833 . The "prov." in front of the title may be interpreted as "provisional". This implies that Fercher had not yet fully attained his new status, and that he might, by the criticism in the letter, have felt that this raise in status could be endangered, causing him to be specifically upset.

Sentence (3) shows the ammunition available: The Kreishauptmann asked the county civil engineer (possibly A. Schaffenrath) to do a survey of the ongoing connection job. The engineer made a rough sketch ("Croquis") of the situation in the cave that originally accompanied the letter but apparently now is either lost or misplaced. That map showed that the breakthrough attempt was not started at the place suggested by the Fercher Survey. As a consequence the "Bergbeamter" leading the work was questioned or better "interrogated" ("einvernommen").

Passage (4) relates what the Bergbeamte said in his defense: He claims that he had been instructed by a Mr. "Bergschaffer" (if this is a title or a family name remains unclear) before he left, that he was to follow only his "hearing" ("sich nur an das Gehör zu halten"), because the map may not be trusted entirely. The hearing then led him to the spot where they have started the actual breakthrough attempt.

Now the attack commences packed into one very long and winding sentence (5): Even though the Kreishauptmann in his function as the chair of the cave board ("Grottenverwaltungskommission") thanks the Bergamt many times ("erkennt in vollem Maße die Gefälligkeit an") for sending the $\mathrm{k} k$ (kaiserlich - königlich) mine officials to survey the cave and to attempt the breakthrough, a public institution ("unter öffentlicher Aufsicht stehender Fond"), such as the cave foundation, cannot possibly pay for a survey which is not correct ("Plan ... der nicht richtig ist") or for a connection which is guided simply by hearing, because sound may be misguided by the joints in the rock. In other words: the cave administration is boldly asking their money back for both the survey and the mining attempt! From Note Idrija 429 we know that the expenses for the survey amounted to $173 \mathrm{f}$. $32 \mathrm{Kr}^{4}{ }^{4}$ or ca. $1750 €$ in today's money and from Note Idrija 747 we learn that Tracha had obtained a minimum of 50 pounds of black powder at $16 \mathrm{f}$. $40 \mathrm{Kr}$. (Kempe, 2005). How much the miners were paid, in addition to the powder, is not known, but easily their costs could have doubled the amount charged for the survey.

The next sentence (6) is advancing one more argument, thereby making the claim inevitable: It explains that the cave administration is fully liable to the province

${ }^{4} 1 \mathrm{f} .=1$ Gulden $=60$ Kreuzer, $\mathrm{Kr}$. board ("Bezirkspräsidium") and that they must submit invoices to them according to the bylaws. It would therefore not be possible to justify expenses with such negative results and the province board would most probably make those persons accountable ("zur Verantwortung ziehen") who carry the responsibility for the failure. This circumstance the mine administration would certainly understand... ("Es dürfte der Einsicht des löblichen Bergamtes nicht entgehen").

After maneuvering the Idrija administration into such a tight corner a helping hand is offered in sentence (7): In order to prevent the investigation by the higher administration it is suggested to the Bergamt that they make those persons accountable (without the pressure of the superior administration) who carry the responsibility for either the inaccuracy of the map or the failure of the breakthrough. They should also calculate the cost of the connection passage, which so far has not reached more than one "Klafter" (ca. $2 \mathrm{~m}$ ) in depth even though the miners have been working in two daily shifts.

In the final sentence (8) the cave administration sets a time line for the response: The result of the demanded official act ("gefälligst einzuleitenden Amtshandlung") are to be related as soon as possible ("in möglichst kürzester Zeitfrist") in order to issue orders that minimize ("mindest lastspielige Weise") the costs for the cave fund.

All in all, and in spite of the many polite and flowery phrases, this is a rock-hard letter, very hostile and not at all timid towards the Idrija administration. One has to wonder about it because it must surely pollute any further cooperation between the two administrations. After all, the Idrija mine did not ask for the full expenses of the survey earlier in the year but only for travel expenses ("Reisespesen") of the participants (Kempe, 2005). Even if there would be small inaccuracies in the survey, the Fercher map is far superior to the previous Foyker map (about which little is known; Hohenwart, 1830) that covered the main passage only. Even thinking about demanding this money back is rather unscrupulous. It must have been clear that this letter also ended any further attempt of the Idrija mine staff to open the connection.

Apparently the mine administration passed the letter of the Grottenverwaltung directly to Fercher. His angry and upset response of September $8^{\text {th }}$ to the Bergamt that transmitted it in turn to the Grottenverwaltung is preserved (Kempe, 2005, Appendix). In it Fercher avoids any answer with regard to the financial demands (which probably was the best strategy), rather he points out that the survey was not meant to be of the highest precision and that it was not made to accurately predict the distance between the two passages (simply because it was not known before that they would end so near to 
each other). He also points out that the breakthrough might be somewhat longer than expected from the map, but that it will be completed sooner or later. In order to settle the dispute he suggested to the mine administration that the passages in question should be resurveyed. This would yield the exact distance to be drilled though. Furthermore he estimated that the break-through could be done at a cost of 50 Gulden per Klafter by two miners without supervision. This sounded like a very logical plan that, however, was not pursued since the work on the connection apparently was abandoned for several years. In expectation of the visit of Emperor Franz Josef and Empress Elisabeth, March $11^{\text {th }} 1857$ the breakthrough was finally completed in 1856 and is about 12 $\mathrm{m}$ long (Hitzinger, 1866).

It is a pity that we do not know how this dispute between the two administrations was finally settled, but one can guess that the mine administration did not refund any of the expenses.

\section{NEWLY DISCOVERED INSCRIPTIONS OF THE FERCHER SURVEY}

Apart from the additional letter, we found further evidence of the work of the survey team in Postojnska jama itself. These are three inscriptions, which, together with the Tartarus Panel (Kempe, 2005) form an interesting historic monument. All are written in pencil and relatively small.

The first inscription, written in Latin letters, was found by us on July $19^{\text {th }}, 2005$, a few meters beyond the formerly gated entrance to Pisani rov (Colourful Passage) on the right-hand side (south-wall), about $1.8 \mathrm{~m}$ above the floor. It was written by Johann Fercher himself (Fig. 2) in three lines and reads: "Aufgenohmen in Monat

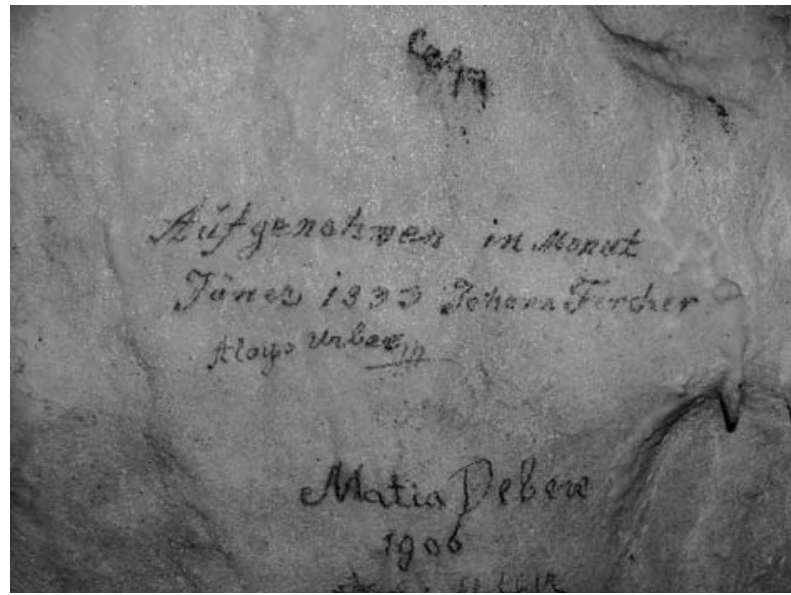

Fig. 2: Pencil inscription of Fercher and Urbas on the south wall at the beginning of Pisani rov, ca. $10 \mathrm{~m}$ from the former gate. (Photo: Kempe).

Jäner 1833 Johann Fercher Aloys Urbas”, followed by a small flourish. In modern German it should be spelled "aufgenommen im Monat Jänner 1833", with "Jänner" being the Austrian equivalent of the High-German "Januar". Translated, the inscription reads: "surveyed in the month of January, 1833". On the Tartarus Panel (Kempe, 2005) Fercher used the same term "aufnehmen" for "to survey". There the inscription is dated to February $7^{\text {th }}$, 1833, showing that the Pisani rov was surveyed earlier and that the survey party apparently worked their way inward, including all the side passages. It is interesting that only two of the survey team left their names here, implying that they may have split up in groups to proceed more rapidly.

The second inscription is found a few meters inside the Pisani rov entrance on the same wall (Fig. 3). It is

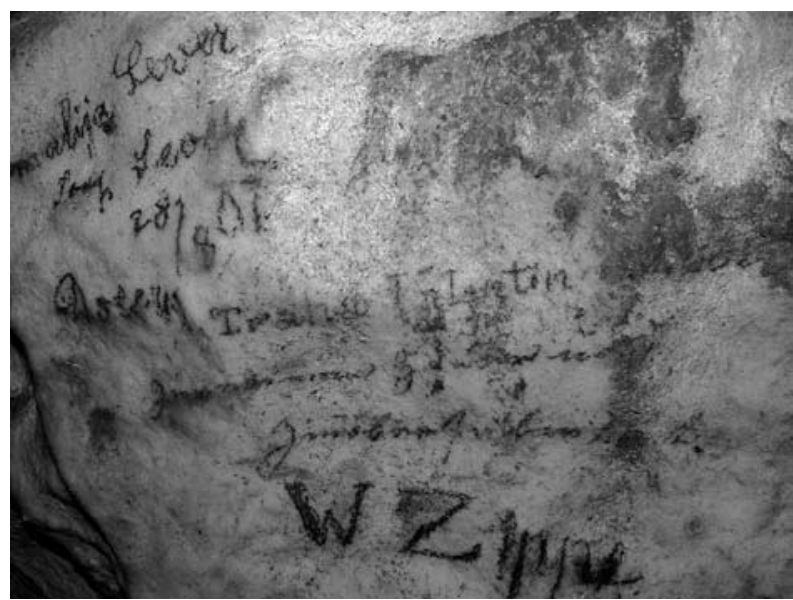

Fig. 3: Pencil inscription of Tracha on the south wall at the beginning of Pisani rov, ca. $5 \mathrm{~m}$ from the former gate. Part of the inscription has been obliterated by a hand imprint by a careless visitor. (Photo: Kempe).

written in Current and reads: "Traha Valentin Zimmermann und Hauer in Idria (?), Zinnober(sublimierer)" with the last part of the word being almost illegible due to dirt from a hand imprint of a careless visitor. It is interesting that Tracha spells his name "Traha" here but in the inscription of Figure 4 he writes "Troha", while in the documents he is clearly spelled as "Tracha" "Troha" would be the correct spelling in Slovenian while the same name in German would be spelled "Tracha" (pers. com. 
A. Kranjc). The translation of the inscription is: "Valentin Tracha, carpenter and miner from Idrija, cinnabar sublimer". It is a pity that the inscription does not carry a date, but Tracha may have visited this part of the cave after the survey, intending to see it as well, possibly not having been part of the survey party. It is further interesting that he lists himself with his professions; apparently Tracha was a carpenter by trade and not a miner in the first place. Cinnabar is the main mercury mineral mercury sulphide $(\mathrm{HgS})$ - that was mined at Idrija. Apparently Tracha carried an additional mining title, being responsible for the sublimation process of the cinnabar or its quality supervision."

The third inscription is also by Tracha (Fig. 4), but it is situated in the Old Adelsberger Grotte, the Imenski rov. In the attempt (work still in progress) to document all of the epigraphs in the historic section of the cave on July $21^{\text {st }}, 2005$, we divided the walls of the passage into panels, counting them from the entrance (Panel 1) to the end. Among the many inscriptions of Panel 9 such as those of Schaffenrath 1829 and Löwengreif 1817, about $150 \mathrm{~m}$ from the passage entrance, Trocha's inscription written in Current is found, inscribed in a nice one-line frame, similar to the frame drawn around the Fercher party inscription on the Tartarus Panel. The text has three lines and reads: „Valentin Traha Zimmermann und Hauer zu Idria bei der Vermessung der Grotte teilgenommen". The last line was deciphered with some difficulty but is in itself

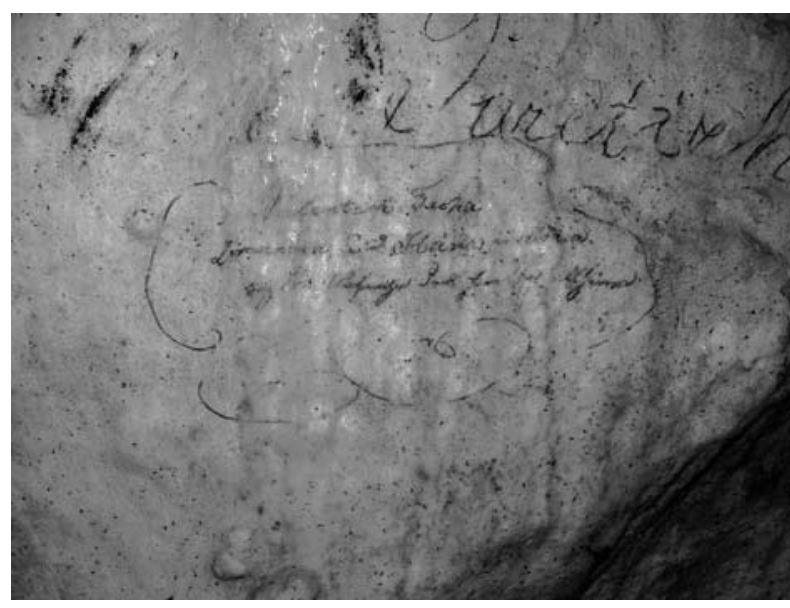

Fig. 4: Pencil inscription of Tracha on Panel 9 in the Old Cave (Imenski rov). (Photo: Kempe).

logical. Here Tracha repeated once more his profession, but he does not do us the favour repeating the cinnabarword, instead he states "participated in the survey of the cave". Interestingly he uses the word "Vermessung" instead of "Aufnahme" as Fercher did. We carefully inspected the walls of the entrance to the Nemški rov, hoping to find a Fercher signature as well, but failed to do so. Possibly this passage was among the first to be surveyed and Fercher did not have the idea as yet to leave a signature.

\section{CONCLUSIONS}

The newly deciphered letter from the Grottenverwaltung to the Idrija administration fills an important gap regarding the circumstances of the Fercher Survey and the failed attempt to break through the blockage of the Mala jama in 1833. In a sense it is very modern, since it is an attempt to claim something like a warranty, asking back money that - as is claimed - was spent on a bad product! The letter also throws light on the structure of the administration at the time and how official supervision was used as a powerful threat against an opponent. It is a pity that the story remains somewhat open-ended, but hope exists, that one or the other document will still turn up, illuminating the circumstances of the Fercher
Survey further. It would be particularly interesting to find the two sketches which originally accompanied two of the notes.

The finding of three more inscriptions of the Fercher Party also gives hope that eventually even more epigraphs may be located, possibly one at every side-passage entrance. Since the pencil signatures are not very conspicuous, they may have been overlooked so far. The four inscriptions discovered as yet, are the most verbal of all of the inscriptions, carrying real information with regard to the history of the cave, not just stating that Mr. or Mrs. So-and-so have been there. 


\section{ACKNOWLEDGEMENTS}

The authors thank Maja Kranjc and Dr. Trevor Shaw for providing the documents for this study. Thanks are due also to Dr. Tadej Slabe, Director of the Karst Research Institute for organizing the access to the Old Cave on July 21 ${ }^{\text {st }}$, 2005. Stanislav Glažar guided us (S.K. and H.P.H. plus our students) on July $19^{\text {th }}, 2005$ through the cave when the pictures of the Pisani rov inscriptions were made. Mr. H. Süß, St. Marien, Österreich, helped in the interpretation of some of the Current abbreviations. Dr. M. S. Werner, Hilo, Hawaii, helped in editing.

\section{REFERENCES}

Bronn, H.C., 1826: Briefe aus der Schweiz, Italien und Südfrankreich im Sommer 1824. - Heidelberg, 652 pp, 4 Lithographs.

Hitzinger, P., ca. 1866: Beschreibung der berühmten Adelsberger Grotte in Krain; nach der vom k.k. Kreis-Ingenier Alois Schaffenrath verfassten Beschreibung neuerlich bearbeitet und mit Zugabe einer Einleitung und einer Beschreibung der neuen Maria Anna-Grotte von P. Hitzinger, dann eines Situationsplanes der ganzen Grotte. - Maximilian Schäfer, Adelsberg, 32 pp.

Hohenwart, F. Graf von, 1830, 1832a, 1832b: Wegweiser für die Wanderer in der berühmten Adelsberger und Kronprinz Ferdinands-Grotte bey Adelsberg in Krain; als Erklärung der von Herrn Aloys Schaffenrath, k.k. Kreis-Ingenieur in Adelsberg, gezeichneten Ansichten dieser Grotte. - Wien, J. P. Sollinger, 3 Vol., $16+9+14$ pp and 21 copperplates (Reprint 1978: Šajn, S., ed.; Introduction: Habe, F. \& Šlenc, J.: Postojnska jama; 1. ed., Postojnska Jama THO; Postojna; 32 pp Introduction, folio).

Kempe, S., 2003: Die alten Inschriften der Adelsberger Grotte / Postojnska Jama. - Die Höhle, 54(2): 36-44.

Kempe, S., 2005: The inscriptions of the Tartarus Panel and the 1833 Fercher-survey, Postojnska jama. - Acta carsologica, 34/1 (13):221-235.
Kempe, S. \& Henschel, H.-V., 2004: Alois Schaffenraths „zerbrochene Pyramide” (Postojnska jama), ein Zeuge glazialer Höhlenvereisung? - Mitt. Verb. dt. Höhlen- u. Karstforsch 50(3): 76-81.

Kempe, S., Bauer, I., Dirks, H., \& Henschel H.-V. (2004): Schaffenrath's Inscription Column in Pisani rov, Postojnska jama. - Acta carsologica, 33/2: 299-312.

Schaffenrath, A., 1834: Beschreibung der berühmten Grotte bei Adelsberg in Krain. - I. Edlen v. Kleinmayr, Laibach, 32 pp, 2 Lithographs.

Schmidl, A., 1854: Die Grotten und Höhlen von Adelsberg, Lueg, Planina und Laas, Text und Atlas. - Wilhelm Braumüller, Wien, 316 pp, 15 Plates.

Schmidl, A., 1858: Wegweiser in die Adelsberger Grotte und die benachbarten Höhlen des Karstes. - 2. Aufl., C. Gerold's Sohn, Wien, 93 pp, 3 Lithographs.

Shaw, T.R., 1992: History of Cave Science, the Exploration and Study of Limestone Caves, to 1900. $-2^{\text {nd }}$ ed., Sydney Speleological Soc., Broadway, New South Wales, Australia, 338 pp.

Shaw, T., \& Čuk, A., 2002: Royal and other noble visitors to Postojnska jama. - Acta carsologica 31(1) (Suppl. 1): $106 \mathrm{pp}$.

Volpi, G. de, 1821: Über ein bey Adelsberg neuentdecktes Paläotherium. - Maldinische Schriften, Triest, $31 \mathrm{pp}, 2$ Plates. 


\section{APPENDIX}

The following text has been transcribed from German Current handwriting. Numbering of the sentences and completions of words are inserted in parentheses. The German is very old-fashioned, enriched with expressions from mining language. It is not possible to translate the text in a way reproducing the style of the letter. Moreover it has orthographic (compared to today's German) and grammatical mistakes; commas are largely missing. For an explanation of the contents and meaning please refer to the text of the paper.

GV 52, den 5.9.1833

An das löbliche k.k. Bergamt zu Idria

(1) Im Vertrauen auf die Richtigkeit des durch gefällige Mitwirkung des löbl.(lichen Bergamtes) aufgenommenen Planes der hiesigen Grotte und auf die Zweckmäßigkeit der Einleitungen des durch die Gefälligkeit des löbl.(ichen Bergamtes) hierher abgesandten Bergbeamten mit 2 Bergarbeitern zur Ausführung des von der Grottenverwaltung beabsichteten Durchschlags hat man die Arbeiten bisher ihren Gang fortgehen lassen. (2) Die Länge ihrer Dauer im Vergleiche mit der dünnen Schicht die nach dem Plan zu durchschlagen war hat dem Herrn Kreishptm (Kreishauptmann) einiges Mißtrauen in diese Arbeit eingeflößt, welche durch die Mittheilungen des Herrn prov.(isorisch) Oberhutmanns Joh. Fercher bei seiner letzten Anwesenheit hier über den Stand der dießfälligen Arbeiten sehr vermehrt wurde. (3) Der zust(ändige) Kshptm (Kreishauptmann) fand sich nun veranlasst den hiesigen Kreisingenieur zu beauftragen über den Stand der Arbeit einen Plan aufzunehmen, und da dieser, wie aus beil.(iegendem) Croquis ersehen werden wolle, entnehmen läßt, daß die Arbeit ganz auf einer anderen Seite begonnen wurde als wo die bereits zu verbindenden Grotten zusammen treffen, so wurde der leitende Beamte über die Ursache davon einvernommen. (4) Er gab als Grund dafür an, daß er von Herrn Bergschaffer (?) vor seiner Abreise die Weisung erhalten habe, sich nur an das Gehör zu halten, indem der Plan nicht ganz verläßlich sey, ... da das Gehör ihn zu der Stelle, wo er anfing, geleitet habe, so habe er seine Arbeit dort begonnen. (5) Der zust(ändige) Kshptm (Kreishauptmann) als Vorstand der Grottenverwaltungskom (mission) erkennt in vollem Maße die Gefälligkeit des löbl.(ichen Bergamtes) in Absendung zweier k k Bergbeamten bei Aufnahme der Grotte das Vorangehen des Durchschlags, kann aber dabei nicht umhin lebhaft zu bedauern und dem löbl. (ichen Bergamte) sein Befremden auszudrücken, daß ein unter öffentlicher Aufsicht stehender Fond, wie es der Grottenfond ist, so bedeutend in Anspruch genommen werde sollte, um einen Plan zu liefern der nicht richtig ist, und zweitens auf das Gerathewohl hin nach dem bei
Klüften so leicht zu täuschenden Gehör einen Durchschlag vorzunehmen. (6) Es dürfte der Einsicht des löbl. (Bergamtes) nicht entgehen, daß die Grottenverwaltung nicht im Stande seyn würde diese für ihren Fond nahmhafte Auslage bei solchem Resultate zu rechtfertigen, um das (?) B(ezirks?)präsidium, wenn ihm die Rechnungen, wie die Statuten der Verwaltungskom(mission) es vorschreiben, vorgelegt werden, wahrscheinlich welche Schuld daran tragen, zur Verantwortung ziehen werde. (7) Um dieser Compromittierung vor höheren Behörden vorzubeugen, wolle es dem löbl.(Bergamt) gefällig seyn, die Herren Bergbeamten denen entweder die Unrichtigkeit des Planes oder der Ausführung des Durchschlags zur Last fällt, schon dermahl ${ }^{5}$, wo es noch ohne Einfluß der oberen Behörden geschehen kann darüber zur Verantwortung zu ziehen, und dabei auch gefälligst die Quantität der bisherigen Leistung bei dem Durchschlage, die kaum eine Vertiefung von einer Klafter beträgt, mit den Kosten dafür, die täglig doppelte Tagschichte für jeden Arbeiter betragen, in Verhältnis zu stellen. (8) Es wird sich erbethen das Resultat der gefälligst einzuleitenden Amtshandlung in möglichst kürzester Zeitfrist eher mitzutheilen um so schnell als möglich Verfügungen $\mathrm{zu}$ erlassen um auf eine für den Grottenfond mindest lastspielige Weise das beabsichtigte Ziel zu erreichen.

Signature: Letz or Betz or Letzner (compare Kempe, 2005)

Adel(sberg) den 5.9. (1)833

\footnotetext{
${ }^{5}$ dermahl = dermal: Austrian for ,jetzt”
} 